\title{
Appendix
}

A.1 South America vegetation cover in 2000 based on remote sensing (Eva et al. 2004)

Vegetation type

Humid Tropical Forest

Dry Tropical Forest

Temperate Forests

Agriculture

Intensive

Mosaic degraded non-forest vegetation

Mosaic degraded forest vegetation

Grass \& Shrubland
Area

$\left(10^{6} \mathrm{~km}^{2}\right)$

6.305

1.467

0.197

2.0247

0.735

1.513

4.456

\section{A.2. Stocks}

Inventory based estimates

Woody biomass

$(\mathrm{PgC})$

121-126
Organic Carbon in Soil $(\mathrm{PgC})$

Amazon forest in 2000

(Malhi et al. 2006)

* assuming Malhi et als. forest area of $5.76 \mathrm{mio} \mathrm{km}^{2}$, and a soil organic carbon content of $29.1 \mathrm{kgC} \mathrm{m}^{-2}$ (Jobaggy and Jackson (2000))

Tropical forest $\quad \sim 95$

Extratropical forests $\sim 15^{* *}$

(Gibbs et al. 2007, their table 3)

**assuming forest biomass density of $200 \mathrm{t} \mathrm{ha}^{-1}$ and forest areas of Paraguay, Chile and Argentina today based on the data in Appendix A.4

Grass and Shrubland

$$
\begin{array}{ll}
\sim 14 * * * & 102 * * * * \\
\sim 12 * * * & 76 * * * * *
\end{array}
$$

Agriculture

***rough estimates based on vegetation type areas estimated by Eva et al. 2004

**** assuming a soil carbon content of $23.0 \mathrm{~kg} \mathrm{~m}^{-2}$ (Jobaggy and Jackson, 2000, their table

3)

***** assuming a soil carbon content of $17.7 \mathrm{~kg} \mathrm{~m}^{-2}$ (value for crops of Jobaggy and

Jackson, 2000)

Remote sensing based estimates of forest carbon in South America (Saatchi et al. 2011)

Country Area (Mha)

Total C $(\mathrm{PgC})(\mathrm{AGB}+\mathrm{BGB}-$ i.e above

and belowground)

Forest definition Tree cover threshold $10 \% / 30 \%$

Brazil

Peru $442 / 596$

Colombia

Venezuela
$73 / 80$

$64 / 84$

47 / 61
Tree cover threshold $10 \% / 30 \%$

$54 / 61$

$12 / 12$

$9 / 10$

$7 / 7$ 
Bolivia

\section{A.3 Population growth}

(Population division of the Department of Economic and Social Affairs of the United Nations Secretariat, World Population Prospects: The 2008 Revision, http://esa.un.org/unpp)

\begin{tabular}{|c|c|c|}
\hline \multicolumn{2}{|c|}{ Year (AD) Population $\left(10^{6}\right)$} & Fossil \\
\hline \multicolumn{3}{|c|}{ Censuses } \\
\hline 1950 & $112^{\prime} 411$ & 0.031 \\
\hline 1955 & $129^{\prime} 039$ & 0.046 \\
\hline 1960 & $147^{\prime} 724$ & 0.060 \\
\hline 1965 & $169^{\prime} 238$ & 0.065 \\
\hline 1970 & $191^{\prime} 430$ & 0.092 \\
\hline 1975 & $214^{\prime} 893$ & 0.112 \\
\hline 1980 & $240 ’ 916$ & 0.139 \\
\hline 1985 & $268^{\prime} 353$ & 0.138 \\
\hline 1990 & $295^{\prime} 562$ & 0.161 \\
\hline 1995 & $321^{\prime} 621$ & 0.192 \\
\hline 2000 & $347^{\prime} 407$ & 0.222 \\
\hline 2005 & $371^{\prime} 658$ & 0.242 \\
\hline 2010 & $393^{\prime} 221$ & \\
\hline
\end{tabular}

Projection (United Nations)

$\begin{array}{ll}2015 & 412^{\prime} 665 \\ 2020 & 430^{\prime} 212 \\ 2025 & 445^{\prime} 428 \\ 2030 & 458^{\prime} 052 \\ 2035 & 468^{\prime} 111 \\ 2040 & 475^{\prime} 482 \\ 2045 & 480^{\prime} 436 \\ 2050 & 482^{\prime} 850\end{array}$

\section{A.4 Deforestation}

Decline of intact tropical forest in Brazil

According to Fearnside 2005 the original forested area in the Brazilian Legal Amazon was $4 \times 10^{6} \mathrm{~km}^{2}$ and there was approx $0.1 \times 10^{6} \mathrm{~km}^{2}$ of 'old' (pre-1970) deforestation forest in the states of Parã and Maranhão.

$$
\begin{aligned}
& \text { Area remaining \% change of area remaining } \\
& \left(10^{6} \mathrm{~km}^{2}\right) \\
& 4.0
\end{aligned}
$$

Deforestation $\left(\mathrm{km}^{2} / \mathrm{yr}\right)$ (Fearnside 2005)

Pre $1970 \quad 4.0$

Deforested area $100 \mathrm{~km}^{2}$

Pre $1978 \quad 3.931$ 


\begin{tabular}{|c|c|c|}
\hline \multicolumn{3}{|c|}{ Deforested area $169.9 \mathrm{k}$} \\
\hline 1978 & 20.4 & 3.890 \\
\hline 1979 & 20.4 & 3.869 \\
\hline 1980 & 20.4 & 3.849 \\
\hline 1981 & 20.4 & 3.829 \\
\hline 1982 & 20.4 & 3.809 \\
\hline 1983 & 20.4 & 3.788 \\
\hline 1984 & 20.4 & 3.767 \\
\hline 1985 & 20.4 & 3.747 \\
\hline 1986 & 20.4 & 3.727 \\
\hline 1987 & 20.4 & 3.706 \\
\hline
\end{tabular}

Deforestation $\left(\mathrm{km}^{2} / \mathrm{yr}\right)$ Brazilian Amazon based on remote sensing (PRODES, INPE)

1988210503.684

$198917770 \quad 3.667$

$199013730 \quad 3.653$

$199111030 \quad 3.642$

$199213786 \quad 3.629$

1993148963.614

1994148963.599

$199529059 \quad 3.570$

1996181613.552

$199713227 \quad 3.538$

$1998 \begin{array}{lll}17383 & 3.521\end{array}$

$199917259 \quad 3.504$

$200018226 \quad 3.486$

$\begin{array}{lll}2001 & 18165 & 3.467\end{array}$

$200221651 \quad 3.446$

$\begin{array}{lll}2003 & 25396 & 3.418\end{array}$

$200427772 \quad 3.399$

$\begin{array}{lll}2005 & 19014 & 3.385\end{array}$

2006142863.373

$2007 \quad 11651 \quad 3.360$

2008129113.352

$20097464 \quad 3.346$

$\begin{array}{lll}2010 & 6451 & 3.340\end{array}$

Deforestation estimates of Achard et al. 2002 (Table 1) based on remote sensing

Forest cover change Latin America Humid Tropical Forest Cover

Date of forest Forest cover Time period of Deforestation rate Total forest cleared cover estimate $\quad\left(10^{6} \mathrm{~km}^{2}\right) \quad$ deforestation est. $\quad\left(\mathrm{km}^{2} \mathrm{yr}^{-1}\right) \quad\left(\mathrm{km}^{2}\right)$

$\begin{array}{ll}1990 & 6.69+-0.57 \\ 1997 & 6.53+-0.56\end{array}$

rate of change 
Annual regrowth area

Rate of change

Annual net cover change

Rate of change

Annual degraded area

Rate of change
$2800+-2200$

$0.04 \%$

$-22000+-1200$

$0.33 \%$

$8300+-0.67$

Deforestation estimates of humid tropical forests 2000-2005 based on remote sensing (Hansen et al. 2008)

Within region forest loss as percent of year 2000 forest area

Brazil

Americas sans

Brazil
$\%$ contribution of region to forest loss in (global) biome 47.8

12.8

(i.e. brazil contributes $79 \%$ of

S American humid tropical Forest loss)

Deforestation data for countries other than Brazil

Andean Amazon

Bolivian Amazon

Date of forest Forest cover Time period of Deforestation rate Total forest cleared cover estimate $\quad\left(10^{6} \mathrm{~km}^{2}\right) \quad$ deforestation est. $\left(\mathrm{km}^{2} \mathrm{yr}^{-1}\right) \quad\left(\mathrm{km}^{2}\right)$ 1984-1987 $\quad 0.447$ 1989-1994 $\quad 0.437$ 1987-1993

(Steininger et al. 2001, Wall-to-Wall, Landsat image analysis)

$$
1990-2000
$$

1506

2000-2005

2247

(Killeen et al. 2007, Wall-to-Wall, Landsat image analysis)

2005/6

0.409

Peruvian Amazon

1985-1990

(Perz et al. 2005)

1999-2005 $\quad 0.66$

(Oliveira et al . 2005, Landsat, "Wall to Wall”)

For explanation of Wall-to-Wall methods see Olander et al. 2008

Colombia - no reliable data found (although see Sierra 2000)

Venezuela - no reliable data found

Ecuador - no reliable data found

Non-Amazon

Paraguay 
$1970-1990$

1990-2000

(Huang et al. 2007)

Argentina

1900 $\sim 0.026000$

1970-79

1980-89

1990-99

2000-05

(Gasparri et al. 2008, Landsat images, Wall-to-Wall)

Forest area data for Andean Amazon

Originally forested year AD

$$
\begin{gathered}
\text { Area } \\
\left(10^{6} \mathrm{~km}^{2}\right)
\end{gathered}
$$

Bolivia

$$
0.505
$$

Colombia (Amazonia \&

Orinoquia)

Ecuador

Perú

Venezuela (Amazonas)

Brazil, legal Amazon

\subsection{6}

4.0
1394 assuming that Atlantic Forest region is where most forest by area is being cleared)

2546

$$
103
$$

138

202

208

Primary forest Area Non-Amazon

Paraguay, Atlantic forest $\quad 0.624$

Argentina $\quad 0.265$

1973

Huang et al. 2007

Chile (native forest area, $\quad 0.184$

1900

Gasparri et al. 2008

i.e. not necessarily primary)

Region Area
(Perz et al. 2005)

$\left(10^{6} \mathrm{~km}^{2}\right)$

0.596

Killeen et al. 2007

0.631

0.130

0.647

0.178

5.082

Oliveira et al. 2007

Fearnside 2005

A.5 Simplified Houghton style book-keeping model to estimate carbon release to the atmosphere in the vane of deforestation

As mentioned in the main text we assume exponential decay of dead organic material left over after a deforestation event: $\Delta C=-\lambda_{\text {decomp }} C \Delta t$ where $\mathrm{C}$ is carbon, $\Delta \mathrm{t}$ a discrete time interval (one year), and $\lambda_{\text {decmp }}$ a decay constant. Thus the carbon release during $t-t_{\text {def }}$ years after the deforestation event in year $t_{d e f}$ is $F_{l d \rightarrow a t}\left(t-t_{d e f}\right)=\lambda_{\text {decmp }}\left(1-\lambda_{\text {decmp }}\right)^{t-t_{d e f}-1} C\left(t_{d e f}\right)$ with

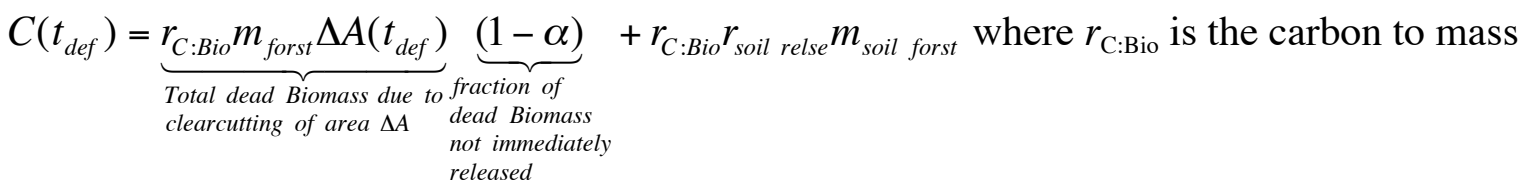
ratio of wood and $m_{\text {forst }}$ is tree biomass per area $\left(\mathrm{MgC} \mathrm{ha}^{-1}\right)$. The total flux to the atmosphere in year $t$ caused by deforestation during previous years and subsequent decomposition of remaining dead organic material is $F_{l d \rightarrow a t}^{t o t}(t)=\sum_{t_{d e f}=-\infty}^{t} F_{l d \rightarrow a t}\left(t-t_{d e f}\right)$ thus 


$$
\begin{aligned}
F_{l d \rightarrow a t}^{\text {tot }}(t)= & r_{C: B i o}\left\{m_{\text {forst }} \alpha \Delta A(t)+\right. \\
& \left.\lambda_{\text {decmp }} \sum_{n \text { def }=1}^{N-1}\left(m_{\text {forst }}\left(1+r_{\text {bgrd:abgrd }}\right)(1-\alpha) \Delta A\left(t-t_{\text {def }}\right)+r_{\text {soil relse }} m_{\text {soil frst }}\right)\left(1-\lambda_{\text {decmp }}\right)^{t-t_{\text {def }}}\right\}
\end{aligned}
$$

Similarly, as already mentioned as well, carbon uptake by land due to spin-up to a new vegetation type after deforestation is assumed to asymptote following $C\left(t-t_{\text {def }}\right)=C_{\text {steady }}\left(1-e^{-\lambda_{\text {rgrwh }}\left(t-t_{\text {def }}\right)}\right)$ where $\lambda_{\text {rgrwth }}$ is the inverse of the spin-up time to the new vegetation type. Therefore $\left.F_{l d \rightarrow a t}\left(t-t_{d e f}\right)=r_{C: B i o} m_{l u} \Delta A\left(t_{d e f}\right)\left(1-e^{-\lambda_{l u}}\right) e^{-\lambda_{l u}\left(t-t_{d e f}\right.}\right)$.

The total flux from the atmosphere to land due to re-establishment of either forest or another vegetation type (we distinguish cultivation, secondary forest and pasture) is then given by $F_{a t \rightarrow l d}^{t o t}(t)=\sum_{t_{d e f}=-\infty}^{t} \sum_{l u} \alpha_{l u} F_{a t \rightarrow l d}\left(t, t_{d e f}\right)$, where $F_{a t \rightarrow l d}\left(t, t_{d e f}\right)$ is carbon uptake in year $t$ in the wake of deforestation in year $t_{d e f}$ and $\alpha_{l u}$ is the fraction of originally deforested land being replaced by land use type $l u$, thus altogether

$$
F_{a t \rightarrow l d}^{t o t}(t)=r_{C: B i o} m_{l u}\left(1-e^{-\lambda_{l u}}\right) \sum_{t_{d e f}=1}^{t-1} \Delta A\left(t_{d e f}\right) e^{-\lambda_{l u}\left(t-t_{d e f}\right)} .
$$

The net flux to the atmosphere in year $t$ finally is $F^{n e t}(t)=F_{a t \rightarrow l d}^{t o t}(t)-F_{l d \rightarrow a t}^{t o t}(t)$.

For the calculations discussed in section 3.2 we use the following numbers:

$\alpha=0.28$ (following Houghton et al. 1983), $\alpha_{\text {lu }}$ we estimate based on statistics of agricultural land use of the Brazilian government (AGROPECUARIA, Brazil, 2011), ratio of below- to aboveground tree biomass $r_{\text {blwg:abgrd }}=0.2$ (Malhi et al. 2010), $\mathrm{m}_{\text {intact forest trees }}=(1+r$ blwgrd:abvgrd $) * 220\left(\mathrm{MgC} \mathrm{ha}^{-1}\right)$ based on RAINFOR forest censuses, $\mathrm{m}_{\text {intact forest_soil }}=291\left(\mathrm{MgC}^{-}\right.$ha $^{-}$ $\left.{ }^{1}\right)$ (Jobaggy and Jackson, 2000), $\mathrm{m}_{\text {pasture }}=8\left(\mathrm{MgC} \mathrm{ha}^{-1}\right)$ (Barbosa and Fearnside, 1996), $\mathrm{m}_{\text {cultivation }}=50\left(\mathrm{MgC} \mathrm{ha}^{-1}\right)$ (Barbosa and Fearnside, 1996), $\mathrm{m}_{\text {secdr forst }}=0.8 * \mathrm{~m}_{\text {intact forst }}, \mathrm{r}_{\text {soil }}$ relse $=0.22$ fraction of soil $\mathrm{C}$ released on conversion of forest to agriculture (Murty et al. 2002) (while according to Murty et al. 2002 this transition of forest to pasture does not lead to significant soil carbon loss), $\mathrm{r}_{\mathrm{C}: \mathrm{Bio}}=0.5$ (ratio of $\mathrm{C}$ to rest of tree biomass by weight),$\lambda_{\text {prim_forest }}=0.1-0.05 \mathrm{yr}^{-1}$ (Achard et al. 2002), $\lambda_{\text {secndry forest }}=0.05 \mathrm{yr}^{-1}$ (Schrodt 2002), $\lambda_{\text {cultiv }}=1 \mathrm{yr}^{-1}, \lambda_{\text {pasture }}=0.5 \mathrm{yr}^{-1}$.

To scale our estimates from the Brazilian Amazon roughly to the full tropical South American forests we use a ratio of 100/79 based on Hansen et al. 2008, table 1 .

A.6 Carbon pool changes estimated with Dynamic Global Vgetation Models

Net Biome Production (NBP)

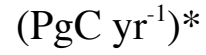

\begin{tabular}{llrlrr} 
Period & \multicolumn{2}{l}{ DGVM name } & & & \\
& Hyland & LPJ & SDGVM & TRI & OCN \\
$1901-1920$ & -0.27 & -0.22 & -0.13 & -0.19 & -0.14 \\
$1921-1940$ & -0.23 & 0.08 & 0.02 & -0.12 & -0.12
\end{tabular}




$\begin{array}{cccccl}1941-1960 & -0.19 & 0.34 & 0.1 & 0.03 & -0.1 \\ 1961-1980 & -0.42 & -0.29 & -0.29 & -0.34 & -0.26 \\ 1981-2000 & -0.77 & -0.41 & -0.59 & -0.47 & -0.35 \\ 2001-2010 & -0.78 & -0.26 & -0.60 & -0.47 & -0.39\end{array}$

*a negative value of NBP corresponds to a flux of carbon to the atmosphere from land vegetation. 